\title{
Factors Affecting Commercial Banks Profitability in Pakistan
}

\author{
DR. MUMTAZ HUSSAIN SHAH \\ Assistant Professor \\ Institute of Management Studies, University of Peshawar \\ SAJJAD KHAN \\ Postgraduate Scholar \\ Institute of Management Studies, University of Peshawar
}

\begin{abstract}
Due to significant contribution of commercial banks in the economic progress of Pakistan, this research has been carried out to analyse the possible effect of different relevant factors on the profitability of commercial banks in the country. Profitability is measured by return on assets (ROA). Using pooled regression analysis on yearly data collected from the annual reports for a panel of 14 commercial banks for eight years from 2007 to 2014, it was found that equity to assets, debts to assets, deposits to assets, bank size and assets management have a significant influence on the commercial banks profitability in Pakistan.
\end{abstract}

Keywords: Commercial Banks, Profitability, and Panel Data.

\section{Introduction}

Financial sector robustness and vigour is very important for sustainable economic growthof an economy (Anuar, Choo, Khan, \&Khan, 2011; Shah, 2016). In services sector banking industry is essential for the speedy disposal of economic and financial transactions. The Pakistani banking industry comprises of Commercial banks, Islamic banks, Foreign banks, Microfinance banks and Specialized banks. State Bank of Pakistan is the regulatory and monitoring agent of all banks operating in Pakistan. In order to increase economic growth of the country it is necessary that these banks should progress and function well. Profitabilityis very important for the banks like any other commercial entity. It helps in absorbing expenses resulting from the operations of the banks. Therefore, it is necessary to understand factors that influence the performance of banks.

Spectacular positive changes are observed in banking sector during the last decade. Performance of banks has improved due to deregulation, financial modernization and technological improvement (Javaid, Anwar, Zaman \& Ghafoor, 2011). The main focus of management is to generate favourablereturns while keeping in mind the intensity of risk exposure. Online and conventional banking plays an important role in the growth of banking sector (Sadeghi \& Farokhian, 2011). Banks are the major suppliers of funds. So, the stability of banks in a country is essentially important. Therefore, understanding the factors which affect the performance of banks is crucial for the policy makers, state banks, regulatory authorities and researchers of corporate finance. 
Though, Pakistani banking sector has shown a massive growth and potential in the last few years as evident from the increase in profitability and stability indicators. However, post 2008 banking sector in Pakistan faces problems of liquidity and solvency which have a notable influence on the profitability of banking sector. Banks can manage critical situations easily if they have massive amount of liquidity. They should be capable of managing debts, deposits, assets management etc. because these factors affect profitability. In economic development of the country, the role of banking sector is significant. In Pakistan, the profit (before tax) reached the highest level of rupees 176 billion in 2014. It showed 44 percent increase as compared to 2013. Similarly, return on assets and return on equity increased by 1.4 percent and 15.9 percent in 2014 when compared to 1.1 percent and 12.3 percent in 2013. The Capital Adequacy Ratio increased from 15.1 percent to 15.5 percent in 2014 (State Bank of Pakistan, 2015).

This research is carried out to find out the factors that affect the profitability of commercial banks in Pakistan from 2007-2014. Usually, profitability is determined by return on assets. The research tested the hypothesis that equity to assets, debts to assets, deposits to assets, bank size and assets management have a significant influence on the profitability of commercial banks in Pakistan.

\subsection{Problem Statement}

To find out the factors that affect commercial banks profitability in Pakistan.

\subsection{Research Questions}

- To find out factors of commercial banks profitability in Pakistan.

- To find out the impact of those factors on profitability of commercial banks in Pakistan.

- To know the correlation between these factors and profitability.

\subsection{Purpose of Research}

The main purpose of this research is to find out how different factors affect the profitability of commercial banks in Pakistan.

\subsection{Research Objectives}

The objectives of the research are:

- To examine the relationship between these factors and profitability.

- To find out the factor that leads to higher profit.

- To find out factors that might be harmful or risky for commercial banks.

- To explore main sources of income generation of commercial banks.

\subsection{Research Hypothesis}

The two main hypothesis of the research are:

$\mathrm{H}_{0}$ : Factors analysed in the study have no significant influence on commercial banks profitability in Pakistan.

$\mathrm{H}_{1}$ : Factors analysed in the study have a significant influence on commercial banks profitability in Pakistan.

\subsection{Scope of Research}

The scope of this study is limited to 14 commercial banks for the time period of 2007 to 2014. Different internal factors are considered and we found some significant results which can be applied to commercial banks in Pakistan only. 


\subsection{Limitations of the Study}

The purpose of this research is to find out the factors effecting commercial banks profitability in Pakistan. Nevertheless, due to some limitations the study does not cover all aspects of the research.

- The research is limited to commercial banks only.

- Only internal factors are included in the research because of lack of data availability.

- Secondary data is collected for 14 commercial banks only, because data of other commercial banks operating in Pakistan was not available for all the variables considered in the study.

- The findings of this research cannot be considered globally because this research is confined to Pakistani Banking sector only.

This paper is divided into five parts. The first part is about introduction of the topic which includes problem statement, research questions, purpose of research, research objectives, hypothesis, scope and limitations of the study. Part two covers literature review. The third one contains population size, sample size, sampling design and methodology, and explanation of dependent and independent variables. Part four is about model specification, estimation techniques, results and data analysis. Whilst part five concludes the paper along with some future recommendations.

\section{Literature Review}

A number of researchers have worked on the factors effecting commercial banks profitability. In this section, we will synthesize these factors effecting commercial banks profitability in Pakistan in the light of previous studies conducted. Bashir (2003) conducted a research on Islamic banking system to analyse the characteristics and financial environment that affect the performance of Islamic banks. He used data of eight Middle Eastern countries for this purpose and analysed different internal and external characteristics. The results showed that equity to total assets and loan to total assets ratios are directly related with profitability. Hijazi and Shah (2004); Awan, Rashid and Rehman(2011) found a negative but statistically significant relationship between debts to assets and profitability.

Al-Mutairi and Al-Omar (2008) had examined the factors affecting the profitability of seven national banks in Kuwait for 1993 to 2005. The results indicated that equity and total assets of a bank are directly related with return on assets (ROA). However, the effect of loan and expenses on profitability is insignificant. Kosmidou (2008) has worked on the determinants of banks' profits in Greece. He took a sample of 23 banks from 1990 to 2002 . He collected data from banks financial statements and used regression analysis for the analysis of data. The results showed that equity to assets ratio is positively and significantly related to profitability. Size of bank is also positively and significantly related to profitability. Chatzoglou, Diamantidis and Vraimaki (2010) studied banking productivity by taking a sample of 10 banks in Greece. They used standard ratio analysis for measuring the performance of banks. Their results indicated that large size banks perform better than medium and small banks. It means that profitability is positively related with banks size. 
Anuar, Choo, Khan and Khan (2011) probed determinants of bank profitability by taking a sample of 16 banks for 2000-2010. They found that bank size is significant which means that as their size increases, the ability of bank to earn more in the market also increase and vice versa. Their results also showed that whether a bank is small or large, the effect of net interest margin (NIM) is positive and significantly contributes to profits. They also found that deposit to asset ratio, and loan to asset ratio are significantly influencing the bank's profitability. Gul, Irshad and Zaman (2011) conducted a research relevant to the problem statement. They studied both internal and external factors that affect profitability. 15 commercial banks were studied bypooled Ordinary Least Square method. They found that both factors have strong influence on the profitability. Larger banks are in a better position than smaller banks. They earn higher profits than smaller banks. So, size of bank is directly related with profitability. Deposits to total assets have a positive and significant effect on profitability. Loans to total assets and equity to total assets ratios have also similar effect on profitability.

Malik (2011) has worked on the factors affecting the profitability of 35 listed life and non-life insurance companies from 2005 to 2009 in Pakistan. The results showed that size of company and capital volume is positively and significantly related with profitability. Leverage ratio has a negative and significant relationship with profitability. Akhtar, Ali and Sadaqat (2011) had worked on micro and macroeconomic indicators of commercial banks profitability. They analysed 22 commercial banks data by SPSS from 2006-2009. Their results showed that total assets, equity and assets management have positive relationship with profitability, whereas, credit risk have an insignificant effect on banks performance. Moreover, the results also showed that bank's size is positively related with profitability. It shows economies of scale, meaning that as size of bank increases, profitability will also increase. Javaid et al. (2011) conducted a research on internal factor analysis of 10 banks profitabilityfor 2004-2008 in Pakistan. To find the effectof total assets, debts, total equity, and total deposits on return on asset (ROA), they used pooled OLS method. Their results showed that these variables have a strong impact on the profitability. It is not necessary that higher total assets would result into higher profits. The effect of loan on profitability is not significant. However, deposits and equity have significant impact on profitability.

Schiniotakis (2012) analysed the factors that affect the profitability of commercial and cooperative banks of Greece. The results showed that profit is greatly influenced by the type of bank and return on assets is positively related with bank capitalisation. Ani, Ugwunta, Ezeudu andUgwuanyi, (2012) studied determinants of banks profitability in Nigeria by taking a sample of 15 banks for the period of 2001 to 2010. Using Pooled Ordinary Least Square the results showed that it is not necessary that higher total assets result in higher profitability because of diseconomies of scale. Equity to total assets, debts to total assets and deposits to total assets ratios contributes to profitability. As these ratios increase or decrease profitability will also increase or decrease.

Obamuyi (2013) examined profitability elements for 20 Nigerian commercial banksfor 2006-2012. The results showed that high capital, interest income as well as favourable economic conditions contributes positively to banks performance. Whilst size of bank has a significant negative effect on profitability. Riaz (2013) studied the 
profitability determinants of 32 commercial banks in Pakistan during 2006-2010. The results showed that bank size, total deposits to total assets ratio and loans to total assets ratios are significantly related to return on equity and have a significant impact on profitability.Sohail, Iqbal, Tariq and Mumtaz (2013) investigated commercial banks profitability in Pakistan. Using cross sectional time series data it was found that internal factors like liquidity, assets composition and debt composition as well as external factors like bank size have a significant impact on banks profitability.

Abdullah, Parvez and Ayreen (2014) probed the macroeconomic determinants of 26commercial banks profitability in Bangladesh for 2008 to 2011. They found that there is positive relationship between profitability, capital adequacy, bank sizeand loan to total assets. Jabbar (2014) examined banks profitability in 31 commercial banks for 20092012. He found that capital and banks size are positively related with profitability. His results also showed that the effect of loan loss provision, deposit growth, and interest expense on profitability is statistically insignificant.

Lim (2015) has worked on the same topic. The researcher collected data of eleven universal banks in Philippines for 2006 to 2013. The study used correlation analysis for determining the linkage between capital structure and profitability and found that debt to assets ratio and profitability are positively related with each other.

\section{Research Methodology}

This part covers population of the study, sample of the study, sampling technique, sample size, sampling design/methodology and data collection, description of dependent and independent variables, as well as the theoretical framework.

\section{a.Population of the Study}

This research is about finding the factors that affect the profitability of banks in Pakistan. There are 48 commercial banks in Pakistan including Government-owned Scheduled Banks, Specialized Banks, Commercial Banks, Development Finance Institutions, Foreign Banks, Islamic Banks, and Microfinance Banks. The population of this study is all the commercial banks that operate in Pakistan.

\section{b.Sample of the Study}

The purpose of the research is to study all the commercial banks in Pakistan but due to some limitations and unavailability of data the sample of the study is reduced to 14 commercial banks.

\section{c.Sampling Design/Methodology}

The research is mostly quantitative in nature for which secondary panel data is used. Data collected from the financial statements of the banks and State Bank of Pakistan website is analysed using pooled OLS. Return on assets is the explained variable. Equity to assets, debts to assets, deposits to assets, bank size, and assets management are the independent variables.

\section{d. Types Of Data}

There are different types of data. The data collected for research depends upon the nature of research. If a research is qualitative in nature, then mostly primary and sometimes secondary data is used. If a research is quantitative in nature, then mostly secondary data is used. The current research is quantitative in nature, therefore, we have used secondary data. 


\section{e. Data Collection}

The data collected for the research is secondary in nature. Secondary data is that data which has already been collected and anyone can access it using internet, reports, and magazines etc. All the data collected for the research is from the annual reports of commercial banks available on the internet.

\section{f. Theoretical Framework}

The most important part in a research is the theoretical framework (Shah \& Afridi, 2015). It shows the number of dependent and independent variables used in the research. In literature review, different variables are identified that affect a bank's profitability. The theoretical framework shows the relationship that exists among dependent and independent variables and the direction of the relationship (Sekaran \& Bougie, 2016).

Figure 1: Theoretical Framework Diagram

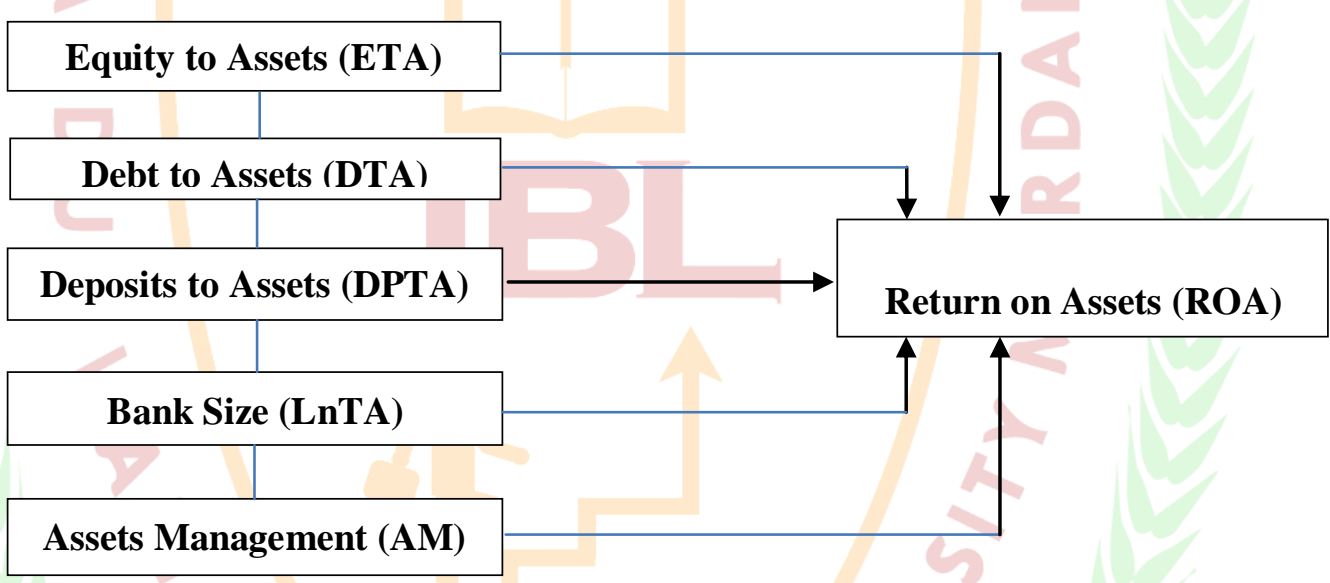

The theoretical frame work diagram shows the direction of association between the dependent and independent variables. All of them are explained below.

\section{g. Dependent Variable - Return on Assets (ROA)}

Return on assets ratio is used for determining how assets are efficiently managed by banks for generating profits. It indicates profits of commercial banks. This ratio is calculated by dividing net profits by total assets. Mathematically: ROA= Net Profit/Total Assets. In most researches, ROA had been taken as dependent variable in order to measure profitability of banks. ROA shows the profit earned per dollar of assets and ability of management to use financial and investment resources of banks for making profits. ROA depends on policy decisions made by a bank as well as uncontrollable factors that are related to the economy and government regulations. ROA is also sometimes called return on investment.

\section{h.Controlling or Independent variables}

The independent variables include in this research are equity to assets, debt to assets, deposits to assets, bank size and assets management.

\section{i. Equity to Assets (ETA)}

Equity to assets ratio shows the amount of assets that are financed with the investment of owners of a firm by comparing total equity to total assets. This ratio can be 
calculated by dividing total equity in a firm by total assets. Mathematically: ETA= Total Equity/Total Assets. ETA can be called as stake of the investors in a company. Companies having high ETA can attract new investors and creditors because they know that the company is performing well, thus, enhancing theiralacrity to investment.

\section{ii. Debt to Assets (DTA)}

Debt to assets ratio shows the amount of assets that are financed with debts rather than owners'equity. It shows the riskiness of the business. This ratio is calculated as dividing total liabilities by total assets. Mathematically: DTA $=$ Total Liabilities/Total Assets. If DTA is greater than 1 , it means that most of the assets of company are financed with debts and if smaller than 1, it means that most of the assets of company are financed with equity. A ratio greater than 1 also indicates that the company is putting itself in higher risk because the assets are lesser in worth than the liabilities and in case of liquidation won't be enough to pay the debts.

\section{iii. Deposits to Assets (DPTA)}

Deposits to assets ratio is another indicator of measuring profitability of commercial banks. DPTA is considered as liability of banks. Customers make current, fixed or saving deposits in banks. These deposits are considered as Bank liabilities because they have to be repaid back to the depositors. Banks invest these deposits in other projects and generate profits on them. Therefore, these deposits are considered as the main sources of banks' funding and hence they influence the profitability of banks. This ratio can be calculated as dividing total deposits by total assets. Mathematically: DPTA = Total Deposits/Total Assets

\section{iv. Bank Size}

Large size banks perform better than small and medium banks because of economies of scale. So, large banks are perceived to earn more profits. In finance research, banks total assets are used as a proxy for bank size. To keep this variable consistent with other ratios, natural logarithm of total assets is taken.

\section{v. Assets Management}

Assets management means assets utilization ratio. This ratio describes how capable assets managers are working to generate profits. It can be calculated by dividing operating profit on total assets. Mathematically: Assets Utilization= Operating Profit/Total Assets.

Table 1: Variables, their Proxies and Symbols

\begin{tabular}{ccc}
\hline Symbols & Variables & Proxies \\
\hline $\mathrm{Y}$ & Return on Assets (ROA) & Explanatory Variables \\
& Net Profit/Total Assets \\
$\mathrm{X}_{1}$ & Equity to Assets (ETA) & Total Equity/Total Assets \\
$\mathrm{X}_{2}$ & Debt to Assets (DTA) & Total Liabilities/Total Assets \\
$\mathrm{X}_{3}$ & Deposits to Assets(DPTA) & Total Deposits/Total Assets \\
$\mathrm{X}_{4}$ & Bank Size (LNTA) & Natural logarithm of Total Assets \\
$\mathrm{X}_{5}$ & Assets Management (AM) & Operating Profit/Total Assets \\
\hline
\end{tabular}




\section{Results and Analysis}

i. Mathematical Equation/Model Specification

This part specifies the variables in a mathematical form and derives a mathematical equation by putting proxies of variables used in the research. The first equation is:

Profitability $_{j t}=\alpha_{0}+$ Independent Variables $_{j t}+\varepsilon_{j t} \quad$ (... 1)

In the equation 1 :

- Profitability is the dependent variable.

- Independent variables are equity, debts, deposits, bank size and assets management.

- $\varepsilon$ represents the error term.

- $\mathrm{t}$ represents the time period.

By putting proxies in equation one it becomes:

$R O A_{j t}=\alpha_{0}+\beta_{1}$ ETA $_{j t}+\beta_{2} D T A_{j t}+\beta_{3} D P T A_{j t}+\beta_{4}$ BankSize $_{j t}+\beta_{5} A M_{j t}+\varepsilon_{j t}$

Where:

- ROA is a proxy used for profitability.

- ETA is equal to total equity divided by total assets.

- DTA is equal to total liabilities divided by total assets.

- DPTA is equal to total deposits divided by total assets.

- Bank size is represented by natural logarithm of total assets.

- AM is equal to operating profit divided by total assets.

\section{j. Data Analysis}

In this sub-section, the issues related to data are analysed and discussed.

i. Descriptive Statistics

The descriptive statistics for all the variables used in this research are given in table two. It summarises the basic information about the data, such as the mean, standard deviation, maximum, minimum and the total number of observations for each variable or their proxies (Shah, 2017b).

\begin{tabular}{ccccccc}
\multicolumn{7}{c}{ Table 2: Descriptive Statistics } \\
\hline Variables / Symbols & $\begin{array}{c}\text { No. of } \\
\text { Obs }\end{array}$ & Mean & $\begin{array}{c}\text { Standard } \\
\text { Deviation }\end{array}$ & Minimum & Maximum \\
\hline $\begin{array}{c}\text { Return on Assets, } \\
\text { ROA }\end{array}$ & 112 & 0.0061 & 0.0136 & -0.0567 & 0.0372 \\
$\begin{array}{c}\text { Equity to Assets, } \\
\text { ETA }\end{array}$ & 112 & 0.1427 & 0.1230 & 0.0406 & 0.6673 \\
$\begin{array}{c}\text { Debts to Assets, } \\
\quad \text { DTA }\end{array}$ & 112 & 0.9065 & 0.0543 & 0.6522 & 0.9776 \\
$\begin{array}{c}\text { Deposits to Assets, } \\
\text { DPTA }\end{array}$ & 112 & 0.7519 & 0.0840 & 0.4487 & 0.8694 \\
$\quad \begin{array}{c}\text { Bank Size, BS } \\
\text { Assets Management, } \\
\text { AM }\end{array}$ & 112 & 19.3393 & 0.9988 & 16.7126 & 21.2938 \\
\hline
\end{tabular}




\section{ii. Testing for Multicollinearity using Variance Inflation Factor (VIF)}

Multicollinearity is the most common problem associated with data. It refers to the existence of perfect or very high correlation between the independent variables included in an econometric model (Shah \& Faiz, 2015). It can be detected by using variance inflation factor (VIF). VIF is defined as "The factor by which the variance of OLS estimator is inflated in the presence of very high Multicollinearity" (Masiero \& Nicolau, 2012). If the VIF value of any independent variable is greater than 10 , then that variable should be excluded from the model in order to overcome multicollinearity (Shah, 2011). Table three shows that VIF of all the models included in the study is less than 10 .

Table 3: Results for Variance Inflation Factor

\begin{tabular}{clr}
$\begin{array}{c}\text { Serial } \\
\text { Number }\end{array}$ & \multicolumn{1}{c}{ Model } & VIF \\
\hline $\mathbf{1}$ & $\mathrm{ROA}_{j t}=\alpha_{0}+\beta_{1} \mathrm{ETA}_{j t}+\varepsilon_{j t}$ & $\mathbf{1 . 0 0}$ \\
$\mathbf{2}$ & $\mathrm{ROA}_{j t}=\alpha_{0}+\beta_{1} \mathrm{ETA}_{j t}+\beta_{2} \mathrm{DTA}_{j t}+\varepsilon_{j t}$ & $\mathbf{1 . 0 4}$ \\
$\mathbf{3}$ & $\mathrm{ROA}_{j t}=\alpha_{0}+\beta_{1} \mathrm{ETA}_{j t}+\beta_{2} \mathrm{DTA}_{j t}+\beta_{3} \mathrm{DPTA}_{j t}+\varepsilon_{j t}$ & $\mathbf{1 . 3 4}$ \\
$\mathbf{4}$ & $\mathrm{ROA}_{j t}=\alpha_{0}+\beta_{1} \mathrm{ETA}_{j t}+\beta_{2} \mathrm{DTA}_{j t}+\beta_{3} \mathrm{DPTA}_{j t}+\beta_{4} \mathrm{Bank}_{\mathrm{Size}}+\varepsilon_{j t}$ & $\mathbf{1 . 4 5}$ \\
$\mathbf{5}$ & $\mathrm{ROA}_{j t}=\alpha_{0}+\beta_{1} \mathrm{ETA}_{j t}+\beta_{2} \mathrm{DTA}_{j t}+\beta_{3} \mathrm{DPTA}_{j t}+\beta_{4}$ Bank Size $_{j t}+$ & $\mathbf{1 . 6 8}$ \\
\hline
\end{tabular}
measured through the correlation between them (Shah \&Qayyum, 2015). Table four provides the correlation matrix for the variables used in the study. It clearly shows that the extent of correlation between the variables is within the accepted range of $\rho<$ 0.90(Shah, 2017a).

Table 4: Correlation Matrix

\begin{tabular}{cccccccc|c|}
\hline Serial No & Variables & $\mathbf{1}$ & $\mathbf{2}$ & $\mathbf{3}$ & $\mathbf{4}$ & $\mathbf{5}$ & $\mathbf{6}$ \\
\hline $\mathbf{1}$ & Return on Assets & 100 & & & & & \\
$\mathbf{2}$ & Equity to Assets & -21 & 100 & & & & \\
$\mathbf{3}$ & Debts to Assets & -06 & -20 & 100 & & & \\
$\mathbf{4}$ & Deposits to Assets & 26 & -41 & 49 & 100 & & \\
$\mathbf{5}$ & Bank Size & 56 & -48 & 36 & 39 & 100 & \\
$\mathbf{6}$ & Assets Management & 82 & -35 & -01 & 21 & 59 & 100 \\
\hline
\end{tabular}

Moreover, to check for the existence of heteroscedasticity the Breusch / Pagan Cook Weisberg test was conducted (Shah \& Samdani, 2015). The test statistics shows the existence of heteroscedasticity in the dependent as well as the explanatory variables with the following p-values 0.0000 . Therefore, the regression results given in table five are after controlling for heteroscedasticity (Shah \& Khan, 2016), that is, after applying the robust option in each of the regressions. The estimation results are provided as table five. The first column shows that with the increase in the proportion of equity in assets the profitability of the firms decreases. A similar relationship was found in the results of Malik (2011), Obamuyi (2013) and Nisar (2015). Whereas, the increase in debts proportion as a percentage of assets have mixed effect on a firm's performance. In column three it is evident that it positively influences return on assets. On the contrary in regression four and five it exerts a negatively significant effect. Somewhat related effect was given byHijazi and Shah (2004). Deposits to assets, Bank size and assets management all positively affect the profitability of Pakistani commercial banks. The 
value of R-square increases gradually with the introduction of a new variable exhibiting the importance of each of them. Deposits to assets, relationship with banks performance is consistent with the findings of Gul et al. (2011) and Javaid et al. (2011). Bank size symbolising economies of scales have a significant positive sway on banks profitability in line with the results of Kosmidou (2008). The value of assets management is 0.4051. It means that assets management is positively related with return on assets. If we increase assets management by 1 unit, then return on assets will increase by 0.4051 units. A similar relationship was found byAkhtar et al. (2011).

Table 5: Regression Analysis

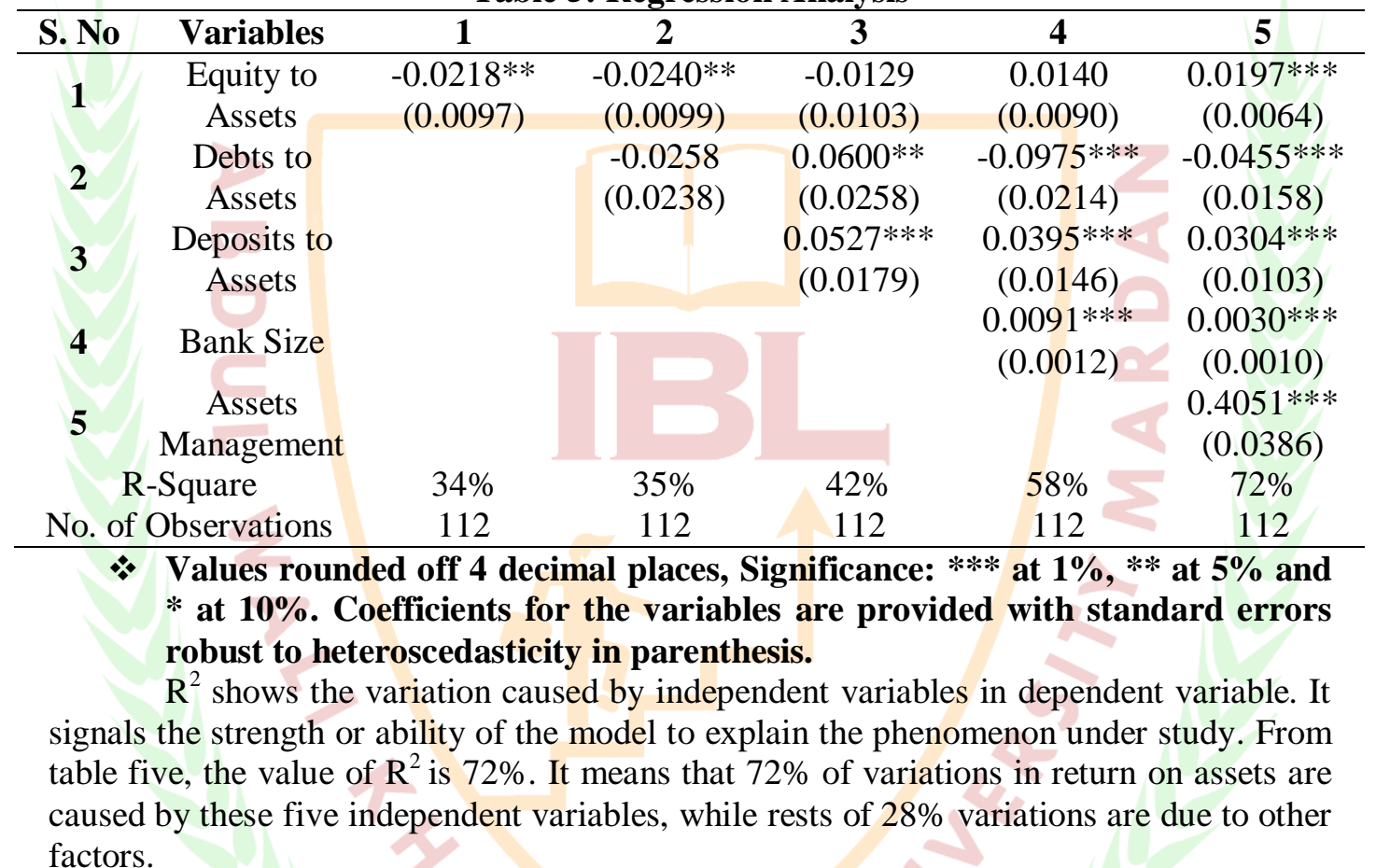

\section{Conclusion}

Banks play a key role in the development of the country. Over the last decade, banking sector in Pakistan had shown a considerable expansion. Commercial banks take deposits from customers and provide loans to various types of businesses, industries, households, individuals, employees etc. This research is carried out to find the factors that affect profitability of commercial banks in Pakistan. The data set consists of 14 commercial banks in Pakistan from 2007 to 2014. Five independent variables were chosen from literature and theoretical relevance such as: equity to assets, debts to assets, deposits to assets, bank size and assets management to gauge their effect on return on equity.

The results show that equity to assets, debts to assets, deposits to assets, bank size and assets management are significantly related with profitability and hence affect the profitability of commercial banks. From the analysis of t-statistics, p-values and confidence intervals, we are able to reject null hypothesis and accept alternative hypothesis for the variables which means that the stated variables have a significant 
influence on the profitability of commercial banks in Pakistan. Future studies can extend the current work by including other independent variables such as current ratio, interest rates, lending and borrowing, total expenditures to total assets, staff expense to total assets, investments to total assets, and taxation and regulation indicators. Another extension could be the examination of different factors that affect profitability of small or large and low or high profit banks.

\section{References}

Abdullah, M. N., Parvez, K., \& Ayreen, S. (2014). Bank specific, industry specific and macroeconomic determinants of commercial bank profitability: A case of Bangladesh. World, 4(3).82-96.

Akhtar, M. F., Ali, K., \& Sadaqat, S. (2011). Factors influencing the profitability of conventional banks of Pakistan, International Research Journal of Finance and Economics, 66, 117-124.

Al-Mutairi, A., \& Al-Omar, H. (2008).Bank-specific determinants of profitability: The case of Kuwait.Journal of Economics and Administrative Sciences, 24(2), 20-34.

Ani, W. U., Ugwunta, D. O., Ezeudu, I. J., \& Ugwuanyi, G. O. (2012). An empirical assessment of the determinants of bank profitability in Nigeria: Bank characteristics panel evidence. Journal of Accounting and Taxation, 4(3), 38-43.

Anuar, M. A., Choo, L. G., Khan, F., \& Khan, H. (2011).Determinants of bank profitability in Pakistan: A case study of Pakistan banking sector, World Applied Sciences Journal, 15(10), 1484-1493.

Awan, T. N., Rashid, M., \& Rehman, M. Z. (2011).Analysis of the determinants of capital structure in sugar and allied industry,International Journal of Business and Social Science, 2(1), 221-229.

Bashir, A. H. M. (2003). Determinants of profitability in Islamic banks: Some evidence from the Middle East, Islamic Economic Studies, 11(1), 31-57.

Chatzoglou, P. D., Diamantidis, A. D., \& Vraimaki, E. (2010). Banking productivity: An overview of the Greek banking system, Managerial Finance, (36)12, 1007-1027.

Gul, S., Irshad, F., \& Zaman, K. (2011).Factors affecting bank profitability in Pakistan.The Romanian Economic Journal, 1(39), 61-87.

Hijazi, T., \& Shah, A. (2004). The determinants of capital structure of stock exchange listed non-financial firms in Pakistan. The Pakistan Development Review,43(4), 605-618.

Javaid, S., Anwar, J., Zaman, K., \& Ghafoor, A. (2011). Determinants of bank profitability in Pakistan: Internal factor analysis. Journal of Yasar University, 23(6), 3794-3804.

Jabbar, H. (2014). Determinants of banks profitability.IOSR Journal of Business and Management, 16(1), 109-111.

Kosmidou, K. (2008). The determinants of banks' profits in Greece during the period of EU financial integration, Managerial Finance, 34(3), 146-159.

Lim, E. (2015). Capital structure and profitability of selected universal banks in the Philippines. Journal of Global Business. 4(1), 24-28.

Malik, H. (2011). Determinants of insurance companies' profitability: An analysis of insurance sector ofPakistan. Academic Research International, 1(3), 315-321. 
Masiero, L., \& Nicolau, J. L. (2012). Tourism market segmentation based on price sensitivity: Finding similar price preferences on tourism activities. Journal of Travel Research, 51(4), 426-435.

Nisar, S. (2015).Determinants of bank's profitability in Pakistan: A latest panel data evidence.International Journal of Economics, Commerce and Management.3(4), $1-16$.

Obamuyi, T. M. (2013). Determinants of bank's profitability in a developing economy: Evidence from Nigeria.Organizations and Markets in Emerging Economies.4(2), 97-111.

Riaz, S. (2013).Profitability determinants of commercial banks in Pakistan. In Proceedings of 6th international Business and Social Sciences research Conference.3-4 January, 2013, Dubai, UAE.

Sadeghi, T., \& Farokhian, S. (2011). The role of behavioral adoption theories in online banking services.Middle East Journal of Scientific Research, 7(3), 374-380.

Schiniotakis, N. I. (2012). Profitability factors and efficiency of Greek banks.EuroMed Journal of Business, 7(2), 185-200.

Sekaran, U., \& Bougie, R. J. (2016).Research methods for business: A skill building approach. John Wiley \& Sons.

SBP, (2015).Annual Report, State Bank of Pakistan.

Shah, M. H. (2011).Essays on foreign direct investment in developing countries (Doctoral dissertation, University of Leicester).

Shah, M. H., \& Afridi, A.G. (2015). Significance of good governance for FDI inflows in SAARC countries.Business \& Economic Review. 7(2), 31-52.

Shah, M. H., \& Faiz, M. (2015). Terrorism and foreign direct investment: An empirical analysis of SAARC countries. City University Research Journal, 5(2), 219-233.

Shah, M. H., \& Qayyum, S. (2015). Impact of double taxation treaties on inward FDI in Latin American and Caribbean developing countries.Business \& Economic Review. 7(1), 1-18.

Shah, M. H., \& Samdani, S. (2015). Impact of trade liberalization on FDI inflows to D-8 countries.Global Management Journal for Academic \& Corporate Studies, 5(1), 30-37.

Shah, M. H. (2016).The effect of macroeconomic stability on inward FDI in African developing countries.International Journal of Business Studies Review.1(1), 111.

Shah, M. H., \& Khan, Y. (2016).Trade liberalization and FDI inflows in emerging economies.Business \& Economic Review, 8(1), 35-52.

Shah, M. H., (2017a). Significance of WTO's trade related investment measures (TRIMS) agreement for inward FDI in Sub-Saharan Africa. City University Research Journal, 7(1), 17-29.

Shah, M. H., (2017b).Political institutions and the incidence of FDI in South Asia.Business \& Economic Review, 9(1), 21-42.

Sohail, N., Iqbal, J., Tariq, H., \& Mumtaz, R. (2013). Determinants of commercial banks profitability: Panel data evidence from Pakistan. Research Journal of Finance and Accounting, 4(10), 67-76. 